\title{
Turkey's Budgetary Responses to the Pandemic and Comparison of the Stringency Level of Interventions in Turkey and Countries in East, South, and Southeast Asia
}

\author{
Gonca Güngör Göksu ${ }^{1}$
}

\section{ARTICLE INFO}

Submitted : 24.07.2021

Revised : 21.10.2021

Accepted : 30.10.2021

Available : 25.12 .2021

iThenticate similarity score: $8 \%$

JEL classification:

$\mathrm{H} 50, \mathrm{H} 61, \mathrm{H} 62$

Keywords:

COVID-19, Budgetary

Responses, Stringency Level, Turkey, Asian

Countries

\begin{abstract}
A B S T R A C T
This study analyses strategies for responding to COVID-19 via considerations of the Turkish state budget, the effects of the pandemic, and projections of macroeconomic and fiscal indicators. Additionally, the stringency level of Turkey's interventions in the pandemic is examined by comparing the responses of countries in East, South, and Southeast Asia. The aims of the study are to analyse Turkey's fiscal responses to COVID-19 and to assess the first-year realization results and future estimates of all selected countries in terms of economic and fiscal. Another objective is to compare the level of rigour of the Turkish government's interventions with that of selected Asian countries using various indices calculated by the Oxford COVID-19 Government Response Tracker (OxCGRT). Data belonging to macroeconomic and fiscal indicators of Turkey were examined from 2019 to 2023 using proportional analysis, and countries' response indices were calculated by daily averaging data from OxCGRT between March 11, 2020, and February 28, 2021. The study includes comparative results based on the relationship between fiscal responses and the rigour level of interventions. The originality is the first study that comprehensively examines Turkey's responses to the COVID-19 and its effects on state budgeting in the short and medium-terms. It is reported that the Turkish government has taken decisive actions in the face of the pandemic when compared to Asian countries, but response costs have driven significant increases in the planned levels of budget and borrowing.
\end{abstract}

Cite this article as: Güngör Göksu, G. (2021). "Turkey's Budgetary Responses to the Pandemic and Comparison of the Stringency Level of Interventions in Turkey and Countries in East, South, and Southeast Asia", International Journal of Public Finance, 6(2), 263-290.

\footnotetext{
${ }^{1}$ Assoc. Prof. PhD., Sakarya University, Department of Public Finance, ORCID: 0000-0003-0230-7391, ggungor@sakarya.edu.tr
} 


\section{Introduction}

The crisis created by the COVID-19 pandemic, which has been described as an "extremely complex, trans-boundary mega-crisis on a global scale" (Christensen \& Laegreid, 2020: 774), includes tragic challenges, and the pandemic has impacted economic growth and other development factors (Mok et al., 2020) across the globe. According to Angel Gurria, the Secretary-General of the Organisation of Economic Cooperation and Development (OECD), compared to the 2008 Global Financial Crisis (GFC), this crisis has caused more severe economic and social problems (Chan, 2020), and conditions have been growing worse than those experienced between 2008 and 2009. Economic projections based on COVID-19 have also shown that the pandemic recession will be deeper than the GFC (McNichol et al., 2020). Likewise, according to the projection of the International Money Fund (IMF; IMF, 2020a), depending on the severity of the outbreak, such a global recession will be worse than the GFC (Beh \& Lin, 2021). It is further estimated that the pandemic will continue to have serious negative consequences for the growth of socio-economic prosperity in many countries (Gössling et al., 2021).

In response to the GFC, state budgets in different countries mainly focused on economic stimulus. By contrast, pandemic-prioritised budgets have focused on COVID19 treatments to control the outbreak and bailouts, in addition to the economic stimulus (Liao et al., 2020). To support public health, social programs, employees, and employers, many governments have introduced significant fiscal measures, such as extra allowances, tax withholdings, loans, and debt relief in their COVID-19 emergency budgets (Grossi et al., 2020). Relevant economic relief policies play an essential role in protecting individuals (Furman et al., 2020) and supporting sectors affected by the reduction of aggregate demand and supply.

It should be noted that "budgeting has become the great issue of our time" (Ferry \& Eckersly, 2011: 15). Effective responses to a pandemic through the state budget take two forms: first, emergency budget expenditures should play a significant role in controlling the contagion of the virus during the quarantine period; second, the economic crisis arising from the pandemic should be controlled using public resources at the appropriate time (Kim, 2020). Thus, the COVID-19 crisis has highlighted the importance of government-led policies and well-resourced public finance (Andrew et al., 2020). Following the outset of COVID-19, state budgets have become more critical (Heald \& Hodges, 2020) than in past periods, thanks to dramatically increasing debts and deficits in many countries (Anessi-Pessina et al. 2020). Because it is estimated that governments will encounter liquidity challenges in the short term and suffer from revenue declines in the long-term (Felix, 2020), most countries around the world have encountered serious budget deficits and debt levels due to COVID-19 (Annessi-Pessina et al., 2020). While governments have given importance to public expenditures to flatten the curve and support businesses and households, state revenues charged, especially sales taxes, have fallen significantly in budgets because of decreased personal consumption expenditures in many sectors (Clemens \& Veuger, 2020). 
A number of studies address the budgetary responses to COVID-19, and most of them focus on central government budgeting in different countries, such as China (Wu \& Li, 2020), India (Jose et al., 2020; Balajee et al., 2020), Japan (Ando et al., 2020), South Korea (hereafter Korea; Kim, 2020), Taiwan (Liao et al., 2020), Pakistan (Ashfaq \& Bashir, 2020), some South Asian countries (India, Nepal, and Sri Lanka; Upadhaya et al., 2020), Indonesia (Olivia et al., 2020), Russia (Vakulenko et al., 2020), Norway, (Christensen \& Laegreid, 2020), Estonia (Raudla \& Douglas, 2020), the United Kingdom (Heald \& Hodges, 2020), Finland, Norway, and Sweden (Argento et al., 2020). The common aim of these studies is to assess the role and effectiveness of state budgets in mitigating economic, social, and health challenges. However, a smaller body of research has highlighted the responses of local administrations to the pandemic in India (Dutta \& Fisher, 2020), the Czech Republic and Slovakia (Nemec \& Spacek, 2020), the United States of America (Felix, 2020; Williams, 2020), and the United Kingdom (Ahrens \& Ferry, 2020).

Not only have policymakers considered extraordinary and innovative measures to address public health issues, but they have also supported economic stability and recovery (Withers et al., 2021) through fiscal tools. Although governments in Asia have tried to provide a normalization process and mobility in the region, ambiguous health results and increasing case numbers have forced their attempts to control outbreaks (Mok et al., 2020). Turkey's reactions to COVID-19 have differed from fiscal measures applied to past crises in terms of both content and significance. The general preference of Turkey in the past crisis was to reduce spending and increase taxes. Whereas policies to reduce or postpone taxes and increase spending have been preferred to stimulate aggregate supply and demand in the COVID-19 crisis. Despite the government's strong fight against the economic crisis caused by the pandemic, vulnerable people and many industries have been severely affected by COVID-19 in Turkey. It is further expected that the long-term outcomes of the pandemic will continue to have implications for state and local government budgets and fiscal governance. In response to the COVID-19 crisis, the Turkish government implemented an emergency budget in 2020 in a coherent manner with other developed and developing countries. This study focuses on the Turkish case to analyse state budgetary responses to COVID-19 and examines strategies to address COVID-19 in the context of the Turkish state budget. Moreover, the study addresses the effects of the pandemic on Turkey's economic and fiscal structure. The notion of the state budget is used as synonyms with the central government budget throughout the study.

Emergency management requires preparedness and a warning flexibility system that is responsive to various crises and emerging circumstances (Oh, 2020). In the second part of the study, to determine the consistency and rigour of Turkey's interventions in the outbreak, Turkey's four index scores from the COVID-19 Government Response Tracker (OxCGRT) are compared with those of 22 countries in East, South, and Southeast Asia. While writing this paper, because the index scores for March 2021 were not yet published for all researched countries, the researcher decided that the average index scores were established from March 11, 2020, when the World Health Organization (WHO) declared COVID-19 as a pandemic, to February 
28, 2021. The reason for comparing Turkey with various Asian countries is that no serious outbreaks occurred prior to the start of COVID-19 in Turkey, whereas the majority of Asian countries studied have experienced outbreaks, such as SARS and MERS, in the past. While cases of SARS were identified in China, Singapore, Vietnam, Hong Kong, Thailand, India, Malaysia, Mongolia, the Philippines, Indonesia, and Taiwan (An \& Tang, 2020), MERS cases were observed in China, Malaysia, the Philippines, Korea, and Thailand (FAO, 2021). Pre-established institutional information in these countries has helped them respond better to COVID-19 than most other countries worldwide (An \& Tang, 2020). For example, the Association of Southeast Asian Nations (ASEAN) carried out 21 outbreak preparedness programs between 2003 and 2019 (Djalante et al., 2020). This study helps to determine the severity of Turkey's response to the outbreak compared to countries that have experienced epidemics prior to COVID-19.

Drawing on secondary sources, such as official data, political reports, and relevant scholarly articles, the overall aims of the paper are twofold. The study's main contribution is to analyse the budgetary responses of Turkey to COVID-19 comprehensively and to address the effects of the pandemic on economic and fiscal structure; in doing so, the study aims to offer insights into the future. The second contribution is to compare the stringency levels of Turkey's interventions to Asian countries with prior experience of pandemics. It is also intended to examine the pandemic effects on the economic and fiscal structures in the selected East and Southeast Asia countries between 2020 and 2021.

The studies discussed in Turkey's budgetary responses generally consider budgetary responses in terms of revenues and spending (Özcan, 2020; Güngör-Göksu, 2020; Şanver, 2020). However, these studies did not consider the rigour and consistency of a country's interventions together with budgetary responses, including income, expenditure, and borrowing. It is known that economic, fiscal, health and social measures exert strong pressure on the budgets of states. Accordingly, this analysis will provide multiple perspectives on both the rigour of the responses and the budget. However, the study does not provide in-depth information on the economic and fiscal measures of the Asian countries analysed. As mentioned previously, the fiscal responses of these countries have already been debated in other written studies on the region by local researchers. The pandemic impacts on leading economic and fiscal indicators within included countries in the study have been evaluated between 2020 and 2021. The article attempts to address the following critical research questions:

\section{1: How has COVID-19 affected Turkey's economic and fiscal structure?}

2: How has the Turkish government responded to the COVID-19 pandemic through the state budget?

3: What are the trends in economic and fiscal projections for Turkey up to 2023 ? 
4: What are the COVID-19 impacts on the economic and fiscal structure in the selected Asian countries in 2020 and 2021 ?

5: To what extent are Turkey's interventions rigorous and consistent with those of East, South, and Southeast Asian countries?

\section{Analysing the Economic and Fiscal Structure of Turkey Prior to and in the Aftermath of the COVID-19 Pandemic}

This section primarily examines macroeconomic indicators for the period between 2019 and 2023, followed by fiscal indicators and budgetary responses to the pandemic.

\subsection{The Effects of the Pandemic on Macroeconomic İndicators}

When the Turkish economy was assessed before the COVID-19 pandemic, gross domestic product (GDP) growth rates in 2018 and 2019 stood at $2.6 \%$ and $0.9 \%$, respectively (Turkish Statistical Institute, 2021). Since the outset of the pandemic, international institutions have made various projections for Turkish economic growth. According to the optimistic projection of OECD, in 2020, the Turkish economy would decrease by $-4.8 \%$, but in the pessimistic scenario, that rate could reach $-8.1 \%$ (OECD, 2020a). As stated by IMF, Turkey's economy was expected to fall by $-5 \%$ (IMF, 2020b). Fitch Ratings revised the Turkish economic growth forecast from $-3.9 \%$ to $-3.2 \%$ in September 2020 (NTV, 2020). Contrary to all projections, however, Turkey's economy continued to grow in 2020, and GDP growth reached 1.8\% (Turkish Statistical Institute, 2021). Table 1 presents macroeconomic indicators from 2019 to 2023.

Table 1. Realized and Projected Macroeconomic Indicators

\begin{tabular}{lccccc}
\hline \multicolumn{1}{c}{ Macroeconomic Indicators } & $\mathbf{2 0 1 9}$ & $\mathbf{2 0 2 0}$ & $\mathbf{2 0 2 1}$ & $\mathbf{2 0 2 2}$ & $\mathbf{2 0 2 3}$ \\
\hline Economic Growth (\%) & 0.9 & 1.8 & 5.8 & 5.0 & 5.0 \\
\hline Unemployment (\%) & 11.8 & 13.7 & 12.9 & 11.8 & 10.9 \\
\hline Inflation (\%) & 13.2 & 14.6 & 8.0 & 6.0 & 4.9 \\
\hline Current Account Balance/GDP (\%)** $^{*}$ & 1.2 & -3.5 & -1.9 & -0.7 & 0.1 \\
\hline Foreign Trade Volume/GDP (\%)** & 51.4 & 52.7 & 55.4 & 54.7 & 53.7 \\
\hline GDP per person (thousand US dollars)* & 9.127 & 8.599 & 8.661 & 9.317 & 10.033 \\
\hline
\end{tabular}

*2019 and 2020 present the realized data, but 2021, 2022, and 2023 include the projected data.

**2019 includes the realized data, and 2020 shows the projected realization result, while the remaining years contains projected data.

Source: The Medium-Term Programme 2021-2023 by the Presidency of Strategy and Budget and the Turkish Statistical Institute. 
According to Table 1, Turkey's economy has been projected to continue to grow through 2023, so the actual GDP growth doubled from 2019 to 2020, unlike in most countries. Turkey became the third fastest-growing economy in the world, after China and Taiwan. The main underlying factors are an increase in household consumption spending and growth in the industrial sector. In the fight against the pandemic in Turkey, the supply of loans was expanded, and loans from banks supported demand (DW Turkey, 2021). However, despite economic growth, GDP per person declined in 2020. This decrease is explained largely by the fact that the GDP growth rate remained below the population growth rate. In 2020, rising unemployment and inflation rates occurred, with rising unemployment rates closely linked to pandemic conditions. While measures such as the response to the illness caused the dismissal of employees, the increase in the inflation rate is related to the instability of exchange rates. The strongest impact of the COVID-19 crisis was on the current account balance and international trade volume ratios that depend on the market, demand shrinkage, travel restrictions, and quarantine measures at the borders. For 2021, 2022, and 2023, a recovery process based on the control of the COVID-19 pandemic is expected to emerge, and the current account balance, inflation ratio, and GDP per capita are expected to improve until the end of the projected period.

\subsection{Effects of the Pandemic on Fiscal Indicators and Budgetary Responses in Turkey}

Since the first case was reported in Turkey on March 11, 2020, the government has taken various measures to flatten the curve and mitigate the severity of the pandemic's impact on health, the economy, and social life. The importance of budget policies in fighting the outbreak has been understood to protect the economy from recession and increase investment, employment, and production. To address the health, economic, and social challenges arising from the pandemic, the Turkish government announced an emergency budget in mid-March 2020 and mobilized resources. In this context, the government implemented the Economic Stability Shield Package, along with budgetary responses that aimed to mitigate the devastating impact of the pandemic on health, economy, and society and to protect individuals and firms.

The Economic Stability Shield Package, which increased public expenses despite declining public revenues, included loan interest cuts led by public banks, tax delays, short-term work allowances, non-refundable monetary support for households, and support for sustainable employment. Furthermore, an expansionary monetary policy was implemented to contain the slowdown in economic activities (Presidency of Strategy and Budget, 2020a). Public resources were used to support households, the real sector, and the health system by mobilizing all facilities. Thus, public funding tools were used effectively to combat COVID-19 (Presidency of Strategy and Budget, 2020b).

The first budgetary response to fight the effects of the pandemic was introduced on March 18, 2020, when the Ministry of Treasury and Public Finance announced a fiscal package of TL 200 billion. In May 2020, the total amount of the aid package reached $\$ 240$ billion, equivalent to $5 \%$ of the GDP (Bloomberg HD, 2020). In 
addition, a national solidarity campaign called "We are self-sufficient Turkey" was organized on March 30, 2020. This campaign has accumulated TL 2 billion from philanthropists for citizens affected by the pandemic (We are self-sufficient Turkey, 2021). At the same time, the government mobilized large-scale responses through the proposals of the Scientific Council on COVID-19 and put in practice a number of serious measures, such as prohibiting trips abroad, restricting domestic trips, imposing a lockdown on the weekends, mandating a curfew for citizens over 65 and under 20, and requiring distance education at all levels (Bostan et al., 2020). In the Central Government Budget Law 2020, a total expenditure of 1,095.5 million TL was planned for the state budget, but it reached 1,202.2 million TL with a $10 \%$ increase. While total budgetary revenues were planned for TL 956.6 billion, they rose to TL 1029.5 billion, increasing 8\% (Presidency of Strategy and Budget, 2020a). One reason why the deterioration of the state budget remained within limits is that an unemployment insurance fund was put in place to alleviate the negative impact of the pandemic on the employment sector. Another reason was that households were able to borrow due to low borrowing ratios (Presidency of Strategy and Budget, 2020b).

\subsection{Analysing the Effects of COVID-19 on the Expenditures of the Central Government Budget}

As in other countries, public expenditures rapidly increased to contain the virus and its effects on health, the economy, and society (McNichol et al., 2020) in Turkey. Table 2 shows expenditure items within the central government budget from 2019 to 2023.

Table 2. Expenditure Ratios within the Central Government Budget from 2019 to 2023 (\%)

\begin{tabular}{lccccc}
\hline A.Expenses of Central Government Budget (CGB) $^{*}$ & $\mathbf{2 0 1 9}$ & $\mathbf{2 0 2 0}$ & $\mathbf{2 0 2 1}$ & $\mathbf{2 0 2 2}$ & $\mathbf{2 0 2 3}$ \\
\hline 1. Non-Interest Expenses & $\mathbf{9 0 . 0}$ & $\mathbf{8 8 . 9}$ & $\mathbf{8 7 . 7}$ & $\mathbf{8 7 . 0}$ & $\mathbf{8 7 . 2}$ \\
\hline 1.1 Personnel Expenses & 24.9 & 23.9 & 22.4 & 22.5 & 22.1 \\
\hline 1.2 Social Security Institutions Premium Expenses & 4.3 & 3.9 & 3.7 & 3.7 & 3.7 \\
\hline 1.3 Goods and Services Purchase Expenses & 8.4 & 7.9 & 6.1 & 6.1 & 6.1 \\
\hline 1.4 Current Transfers & 40.0 & 41.4 & 41.5 & 41.8 & 41.0 \\
\hline 1.5 Capital Expenses & 8.1 & 7.7 & 7.1 & 6.3 & 7.1 \\
\hline 1.6 Capital Transfers & 1.6 & 1.2 & 3.4 & 3.1 & 3.4 \\
\hline 1.7 Lending & 2.5 & 2.4 & 2.6 & 2.6 & 2.9 \\
\hline 1.8 Reserve Allowance & - & - & 0.7 & 0.7 & 0.6 \\
\hline 2. Interest Expenses & $\mathbf{1 0 . 0}$ & $\mathbf{1 1 . 1}$ & $\mathbf{1 2 . 3}$ & $\mathbf{1 3 . 0}$ & $\mathbf{1 2 . 8}$ \\
\hline CGB Total & $\mathbf{1 0 0 . 0}$ & $\mathbf{1 0 0 . 0}$ & $\mathbf{1 0 0 . 0}$ & $\mathbf{1 0 0 . 0}$ & $\mathbf{1 0 0 . 0}$ \\
\hline
\end{tabular}

${ }^{*}$ The 2019 and 2020 figures in the table show the results achieved, but 2021, 2022 and 2023 figures show the projected budget.

Source: Prepared using budgetary statistics from the Presidency of Strategy and Budget. 
As shown in the table, interest expenses increased by $1.1 \%$ from 2019 to 2020, and the increase ratio is expected to continue at the end of the 2021-2023 multi-year plan. An important reason for this result is the increase in interest ratios by the Central Bank to control the high inflation rate, which reached $14.6 \%$ at the end of 2020 and the instability of exchange rates. In the most developed countries, monetary policy measures taken to mitigate the impact of COVID-19 on financial markets were implemented in such a way as to reduce interest rates. Turkey, however, has been in a different position with respect to interest rates. In addition, interest expenditures in the budget are projected to fluctuate from $12 \%$ to $13 \%$ between 2021 and $2023^{2}$.

In terms of the proportion of non-interest-related expenditures in the 2020 budget, there was a decrease from 2019 to 2020. In a full item-by-item analysis, decreases occurred in all expenditure items except current transfers. Although discretionary fiscal policies reduced most non-interest expenditure items in the government budget, current and transfer expenditures increased. In battling the outbreak, the increase in current expenditures was directly related to total transfer payments of more than 30.4 billion TL compared to initial budget allocations. Additionally, cash transfers to households affected by the pandemic were a major reason for the increase in current expenditures, and, therefore, the appropriate allocations amounted to over 11 billion TL compared to the initial budget. Between 2021 and 2023, the increase in current transfer payments was expected to continue due to the uncertain effects of COVID-19 and ignorance of the end date of the outbreak. However, a slight drop appeared in lending, as the capital contributions provided to companies with public capital in the rail transport sector were efficient in the second quarter of 2020 (Presidency of Strategy and Budget, 2020a).

\subsection{Analysing the Effects of COVID-19 on the Revenues of the Central Government Budget}

In a crisis, additional costs emerge to help people who have lost their jobs, and resulting income losses lead to budget deficits, as governments must provide urgent public services, such as healthcare, education, and public safety (McNichol et al., 2020). Due to a force majeure event resulting from COVID-19, businesses and taxpayers were unable to meet their obligations during the statutory period. Therefore, the government has taken measures and facilitated practices that favour taxpayers, including the postponement of tax declaration, notification, and payment deadlines (Özcan, 2020). Relevant measures in response to the pandemic have affected government budget revenues. Table 3 displays data from 2019 to 2023 to help analyse changes in central government budget revenue items before, during, and after the outbreak of COVID-19.

\footnotetext{
${ }^{2}$ The Central Bank of the Republic of Turkey increased the interest rate from $11.25 \%$ to $17 \%$ between January and December 2020 and also to 19\% as of March 19, 2021 (the Central Bank of the Republic of Turkey, 2021).
} 
Güngör Göksu, G. (2021). “Budgetary Responses to the Pandemic and Comparison of the Stringency Level of Interventions in Turkey and Asian Countries", International Journal of Public Finance, 6(2), 263-290.

Table 3. Revenue Items within the Central Government Budget from 2019 to 2023 (\%)

\begin{tabular}{|c|c|c|c|c|c|}
\hline $\begin{array}{l}\text { B. Revenues of the Central Government Budget } \\
\qquad(\text { CGB })^{*}\end{array}$ & 2019 & 2020 & 2021 & 2022 & 2023 \\
\hline 1. General Budget Revenues (GBR) Within CGB & 97.3 & 97.5 & 97.7 & 97.9 & 98.0 \\
\hline 1.1 Tax Revenues Within GBR & 82.3 & 85.3 & 86.7 & 87.4 & 87.4 \\
\hline 1.2 Enterprise and Ownership Revenues Within GBR & 9.4 & 5.1 & 4.9 & 3.6 & 3.6 \\
\hline 1.3 Donations and Grants Within GBR & 0.7 & 0.9 & 1.1 & 1.1 & 1.6 \\
\hline 1.4 Interest, Shares and Penalties Within GBR & 6.7 & 8.0 & 6,1 & 10.4 & 6.4 \\
\hline 1.5 Capital Revenues Within GBR & 0.7 & 0.7 & 1.1 & 1.0 & 0.9 \\
\hline 1.6 Debt Recovery Within GBR & 0.2 & 0.1 & 0.1 & 0.1 & 0.1 \\
\hline $\begin{array}{l}\text { 2. Self-Revenues of Special Budget Institutions } \\
\text { Within CGB }\end{array}$ & 2.0 & 1.8 & 1.6 & 1.4 & 1.3 \\
\hline $\begin{array}{l}\text { 3. Self-Revenues of Regulatory and Supervisory } \\
\text { Authorities Within CGB }\end{array}$ & 0.7 & 0.7 & 0.7 & 0.7 & 0.7 \\
\hline CGB Total & 100 & 100 & 100 & 100 & 100 \\
\hline
\end{tabular}

Source: Prepared using budgetary statistics from the Presidency of Strategy and Budget.

Comparison of revenue data from 2019 to 2020 reveals no significant change in the proportions of revenue of the general budget, the revenue of special budgetary institutions, and the revenue of regulatory and supervisory institutions in the central government budget. From 2021 to 2023, it is projected that, although the proportion of general budget revenues will fluctuate between $97 \%$ and $98 \%$, the revenue proportion of special budgetary institutions will decrease slightly. The corresponding decline is projected to continue until the end of 2023, and, thus, the financial autonomy of the institutions involved will be restricted in the multiannual budgetary process. In addition, it is considered that no change in the revenue proportion in the state budget of regulatory and supervisory institutions will occur in the period under review.

When examining general budget revenues from before and after COVID-19 revealed the following: tax revenues increased by $3 \%$; interest, shares, and penalties by $1.3 \%$; and donations and grants by $0.2 \%$. The primary reason for the increase in interest items is that the budget reflects the rise in interest rates by the Central Bank; the second reason concerns penalties for people who did not comply with rules requiring them to stay at home, use masks, and maintain social distance. However, enterprise and ownership revenues declined by $4.3 \%$, while debt recovery revenues declined by only $0.1 \%$. In addition to the statistics shown in Table 3 , data from the Turkish Revenue Administration indicate that the central government budget increased by $15.5 \%$ from 2019 to 2020 , and the total amount of taxes collected in the state budget increased by $19.9 \%$ (Turkish Revenue Administration, 2020). These 
increases are linked to the new normalization process that began in June 2020 because economic activities have accelerated since then, and leading indicators have improved progressively due to reduced measures such as prohibiting trips abroad, restricting domestic trips, imposing a lockdown on the weekends (Presidency of Strategy and Budget, 2020b).

According to IMF, "the COVID-19 pandemic will cause a major decline in tax revenue in most countries. This is caused both directly by the economic slowdown and indirectly by tax policy and administration measures taken in response" (IMF, 2020b: 1). However, although sales tax collection based on lower consumer spending linked to higher unemployment decreased in most countries, it increased in Turkey, and tax collection rose in the second half of 2020. But the increase in tax collection was not caused by income and earnings taxes. Rather, it resulted from a rise of sales taxes, such as value-added taxes and private consumption taxes, above the projected level because the private consumption tax ratios collected on motor vehicles increased significantly in August 2020. In addition, because of the inclusion of private consumption taxes in the value-added tax base, related increases in the ratios of private consumption taxes were directly reflected in value-added tax revenues (Dünya, 2021). For the multiannual budgeting period from 2021 to 2023, it is estimated that tax revenues and donations and grants will continue to increase, but enterprise and ownership revenues will decrease considerably. Apart from the expected fluctuation in interest revenues between $6 \%$ and $10 \%$, there will be no significant change in capital and debt recovery revenues.

\subsection{Analysing the Effects of COVID-19 on the Central Government Budget Deficit}

While fighting the pandemic crisis, increased public expenditures exceeded initial budget allocations, and the postponement of taxes and duties played an important role in the budget deficit. By the end of 2020, the deficit, including interest payments, in the state budget was $-3.4 \%$ of GDP, exceeding its forecast level, and the relevant increase is projected to continue in 2021 as a result of the unknown impact of COVID-19. Table 4 presents the impact of COVID-19 on the budget deficit and projections for the multiannual period between 2021 and 2023.

Table 4. Projected and Realised Central Government Budget Deficits (Share of GDP)

\begin{tabular}{lccccc}
\hline & $\mathbf{2 0 1 9}$ & $\mathbf{2 0 2 0}$ & $\mathbf{2 0 2 1}$ & $\mathbf{2 0 2 2}$ & $\mathbf{2 0 2 3}$ \\
\hline Budget Deficit including Interest Expenditures & & & & & \\
\hline Projected & -3.3 & -2.9 & -4.3 & -3.9 & -3.5 \\
Realized & -3.0 & -3.4 & - & - & - \\
\hline Interest-Free Budget Deficit & & & & & \\
\hline Projected & 0.8 & -1.3 & -1.2 & -0.7 & -0.4 \\
Realized & 0.6 & -2.6 & - & - & - \\
\hline
\end{tabular}

Source: Medium Term Fiscal Plan (2019-2021), (2020-2022), (2021-2023), and the realized 2019 budget data from the Presidency of Strategy and Budget. 
As noted in Table 4, the analysis of the budget deficit is based on interest expenditures and interest-free expenditures. Prior to the pandemic, there was no significant variance between the projected and realized budget deficits. Consequently, the realized budget deficit was below the projected level for both interest expenditures and interest-free expenditures. However, due to COVID-19, significant deviation occurred in both deficit types, and the interest-free budget deficit was double the projected amount. The interest-free budget deficit is closely linked to the significant increase in current and transfers expenditures to support businesses and vulnerable households. Additionally, the increase of the budget deficit, including interest expenditures, has been projected to continue through the end of 2021, and the Central Bank's interest policy is regarded as the reason for this increase. It is expected that the repercussions of the outbreak will continue to impact the fiscal deficit until 2023. The budget deficits in the analysed period are related to the fact that financial sources are inadequate due to the sharp decline in economic activities during the outbreak.

\subsection{Analysing the effects of COVID-19 on the general government debt}

To finance the budget deficit in 2020, domestic borrowing was preferred, and it accounted for $90 \%$ of the total debt in 2020 as part of central government borrowing. At the same time, the external debt ratio remained at $10 \%$. According to the MediumTerm Programme (2021-2023), the EU-defined public debt is expected to be $41.1 \%$ of GDP in 2020, 40.8\% in 2021, 41.6\% in 2022, and 41.8\% in 2023 (Presidency of Turkey, Presidency of Strategy and Budget, 2020b). Graph 1 presents the realized proportion of EU-defined general government debt in GDP on a quarterly basis between the first quarter of 2019 (2019-Q1) and the second quarter of 2021 (2021-Q2).

Graph 1. The Proportion of EU-Defined General Government Debt in GDP as Quarterly (\%)

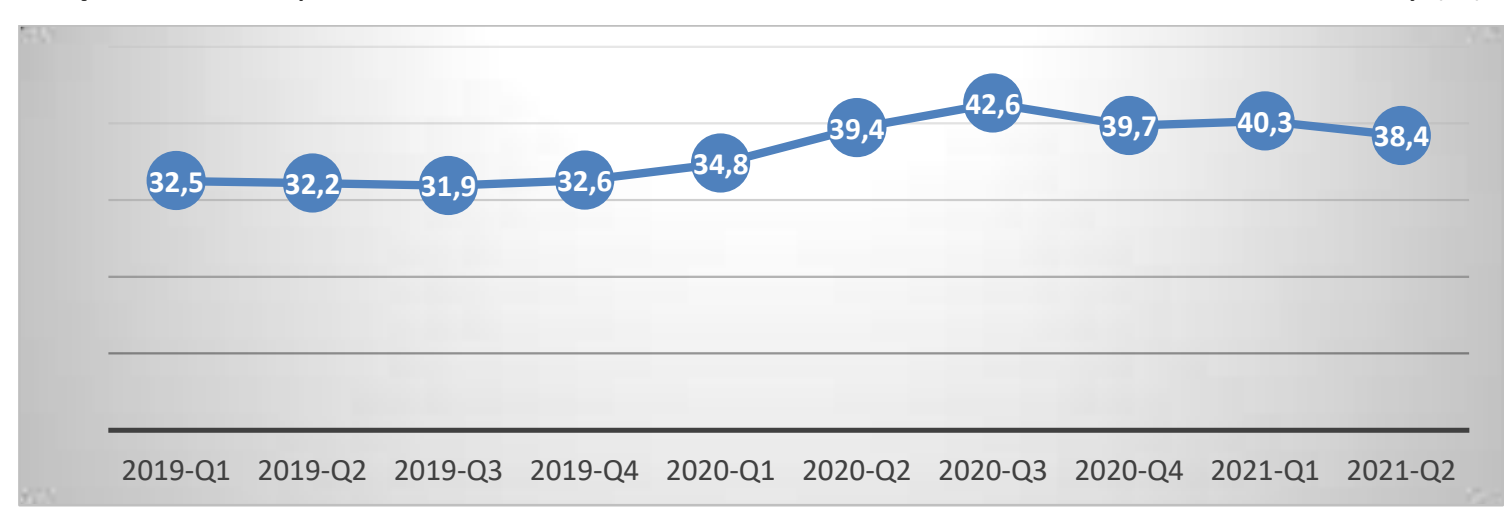

Source: Prepared by using public debt statistics (2019-2021) from the Ministry of Treasury and Public Finance.

As shown in Graph 1, the proportion of EU-defined general government debt in GDP sharply increased from 2019-Q1 to 2021-Q2. The graph clearly reflects the effect of COVID-19 pandemic on Turkey's public debt structure. Additionally, at the end of September 2021, the domestic debt amounted to 1,323,462 million TL, which equals 
$58.3 \%$ of the total government debt stock, and the amount of external debt reached 943,998 million TL, or $41.7 \%$ total government debt (Ministry of Treasury and Public Finance, 2021). Another reason for the rising level of debt is that Turkey has faced multiple natural disasters, including the earthquakes in Elazığ, Malatya, and İmir, the flood in Giresun, Kastomunu, Sinop, and the forest fire in the Eagan and Mediterranean Sea regions which have put economic pressures on the 2020 and 2021 state budgets. After the pandemic and these natural disasters, the Turkish government borrowed from international institutions, such as the World Bank, the Asian Infrastructure Investment Bank, and the Islamic Development Bank. In 2020, the loans included \$300 from the World Bank, \$70 million from the Asian Infrastructure Investment Bank, and \$250 million from the Islamic Development Bank in 2020.

\section{Analysing the Structures' Features of the East and Southeast Asia Countries, and the Changes in the Leading Economic and Fiscal Indicators in the COVID-19 Pandemic}

A new trade bloc made up of countries from East and Southeast Asia has emerged since the 1970s (McDonald et al., 2008), and China, Korea, Taiwan, Hong Kong, Singapore, Malaysia, the Philippines, and Thailand have become the rapidly developing economies in the region (Hsiao \& Hsiao, 2006). As the reasons for the economic growth, the sharp rising in the share of the manufacturing sector in total production and employment, increasing diversification of the industrial output, and an increase in exports, with a focus on manufactured goods, are shown. In addition, the complementarity of the region's economic structures and the dynamism of technology upgrading in response to that of the leading nations have aided the region's overall growth (UNIDO, 2010). Primarily, China has achieved an integral part of the regional trading bloc with expanding trade in intermediate inputs in the region (McDonald et al., 2008). Globalization is also the driving force behind increasing regional integration in East and Southeast Asia (ADB, 207). Furthermore, these countries have some specific features that are the cornerstone of the GDP and unique to the region (Mori \& Elder, 2010; Ohno, 2002):

i. The great diversity of its ecosystem, a population, an ethnic group, a religion, a social structure, and a political system,

ii. Equal diversity of gross domestic product, per capita income, and economic performance,

iii. Sustained Vigorous growth over an extended period across most of the region,

iv. High savings and investment rates are associated with this high growth rate, open economies, export-oriented economies, industrialization, and the general improvement of social indicators,

v. Increasing the labor force depending on population growth affects economic.

The average economic growth ratios of ASEAN-10 countries -Brunei (\%2), Cambodia (7\%), Indonesia (5\%), Laos (6.3\%), Malaysia (4.7\%), Myanmar (6.5\%), the 
Philippines (6.2\%), Singapore (3.1\%), Thailand (\%4.1), and Vietnam (7.1\%)- and the emerging Asia -China (6.6\%), India (6.8\%), Indonesia (5\%), Korea (2\%), Malaysia (4.7\%), Pakistan (1\%), the Philippines (6.1\%), Taiwan (2.9\%), and Thailand (4.1\%)- were respectively $5.2 \%$ and $6.4 \%$ in 2019 . On the contrary, they occurred as $-3.4 \%$ and $-1.7 \%$ in 2020 (OECD, 2021a). In Asia, as in other regions of the world, COVID-19 has touched aspects of people's, including health, social services, and the economy. According to the real data, Chinese GDP grew by $2.3 \%$, but the economies of India, Japan, Indonesia, Korea, Hong Kong shrunk, respectively, by $-7.9 \%,-4.8 \%,-2.1 \%,-1.0 \%$, and $-6.1 \%$ (OECD, 2021b). Moreover, the pandemic has aggravated the extreme poverty for 158 million people in continental Asia and the Pacific below the $\$ 3.20$ per day threshold (UNDP, 2021).

The pandemic effects in the region have been significant because of (i) regional characteristics such as intensity of economic activities, (ii) demographic structure, (iii) urbanization, (iv) having over two-thirds of the world population, (v) holding the most populated cities in the world, (vi) significant industrial activities, (vii) the volume of energy supply and consumption demand (ESCAP, 2020). The extent and content of responses to COVID-19 by countries in the region have varied in accordance with their economic capabilities (Djalante et al., 2020), resulting in greater economic divergence among these countries. In fighting the disease, East Asian countries, such as Japan, Taiwan, Hong Kong, and Korea, have succeeded in mitigating the spread of the virus by taking aggressive measures from the onset of the pandemic. The achievement of some Asian countries is due mainly to rigorous and comprehensive political instruments, economic development, and cultures that foster public cooperation and voluntary compliance (An \& Tang, 2020). However, socio-economic differences between Asian countries have had repercussions for their divergent responses and contexts (Djalante et al., 2020), and the pandemic has affected economic growth, unemployment, poverty, and inequality, especially in South Asian countries (Yadav \& Igbal, 2021). Poverty is, therefore, one of the main reasons that some South Asian countries cannot require strict measures and that vulnerable people benefit less than those in the developed Asian countries (Djalante et al., 2020).

With respect to budgetary responses, fiscal measures vary from country to country. For instance, while China and Taiwan subsidize consumer cheques for vulnerable households, South Korea, Hong Kong, and Japan provide assistance in the form of emergency cash payments ( $\mathrm{Ma}$ et al., 2020). However, it is questionable whether the fiscal stimulus measures taken by the countries analysed are sufficient to meet the gravity of the crisis. It is estimated that rising public debt and budget deficits will lead to restrictions on GDP growth and challenges for fiscal resilience and stability (Upadhaya et al., 2020). Governments' responses, which depend on the countries' levels of development, have varied across Asia, and the least developed countries have generally been less able to resist the impact of the pandemic. Economic structure has played an important part in the fight against the virus, and measures such as social distancing and restrictions on cross-border travel have adversely affected tourismbased economies, such as Bhutan, Nepal, Sri Lanka, and Thailand (UNDP, 2021). 
Table 5 presents the macroeconomic and fiscal indicators for 2020 and 2021 in the selected countries within the study in order to understand the first-year and second-year effects of the pandemic on the economy and fiscal developments in these countries. So that Table 5 can help to determine and compare being affected level by the pandemic of the selected countries, including Turkey too.

Table 5. The Macroeconomic and Fiscal Indicators in the Selected Asian Countries [2020 (real data) \& 2021 (projected data)]

\begin{tabular}{|c|c|c|c|c|c|c|c|c|c|c|c|}
\hline VNM & 2.9 & 3.3 & 26.4 & 28.6 & 3.2 & 16.1 & 21.5 & -5.4 & 46.6 & 2.2 & 3.498 \\
\hline TWN & 3.1 & 3.9 & 23.6 & 39.8 & -0.1 & 14.7 & 19.0 & -4.3 & 33.6 & 14.1 & 32,122 \\
\hline TUR & 1.8 & 13.7 & 31.4 & 26.6 & 14.6 & 29.2 & 34.6 & -5.4 & 36.7 & -5.1 & 8,599 \\
\hline THA & -6.1 & 2.0 & 23.8 & 27.1 & -0.8 & 20.6 & 25.3 & -4.7 & 49.6 & 3.2 & 7,190 \\
\hline SGP & -5.4 & 3.0 & 22.6 & 40.2 & 3.0 & 17.6 & 26.6 & -9.0 & 128.3 & 17.5 & 58,902 \\
\hline PNG & -3.9 & 2.7 & - & - & 1.0 & 13.9 & 20.1 & -6.2 & 49.1 & 13.8 & 2.684 \\
\hline PHL & -9.6 & 10.4 & 17.4 & 20.6 & 2.6 & 19.6 & 25.1 & -5.5 & 47.0 & 3.2 & 3,330 \\
\hline PAK & 0.5 & 4.5 & 15.4 & 14.2 & 10.7 & 15.1 & 23.1 & -8.0 & 87.2 & -1.1 & 1,260 \\
\hline NPL & -2.1 & 4.4 & 31.3 & 30.3 & 6.1 & 21.9 & 27.0 & -5.1 & 41.3 & -0.9 & 1.195 \\
\hline MYS & -5.6 & 4.5 & 19.6 & 24.0 & -1.1 & 20.3 & 25.4 & -5.1 & 67.5 & 4.3 & 10,269 \\
\hline MNG & -5.3 & 7.5 & 24.5 & 20.1 & 3.7 & 28.1 & 37.9 & -2.7 & 76.5 & -4.3 & 3,916 \\
\hline MMR & 3.1 & 1.8 & 32.8 & 28.8 & 5.7 & 16.0 & 21.6 & -5.6 & 39.3 & -3.4 & 1,524 \\
\hline LAO & 0.4 & 0.9 & - & - & 5.0 & 12.0 & 18.5 & -6.5 & 67.9 & -5.7 & 2,625 \\
\hline LKA & -3.6 & 5.0 & 25.9 & 24.5 & 4.5 & - & - & - & 100 & -1.3 & 3,678 \\
\hline KOR & -1.0 & 3.9 & 31.6 & 36.2 & 0.5 & 22.8 & 25.6 & -2.8 & 48.6 & 4.6 & 31,496 \\
\hline JPN & -4.8 & 2.7 & 25.5 & 28.8 & -0.0 & 34.0 & 46.6 & -12.6 & 256.2 & 3.2 & 40,146 \\
\hline IND & -2.1 & 7.0 & 32.3 & 31.9 & 2.0 & 12.3 & 18.2 & -5.9 & 36.6 & -0.4 & 3,921 \\
\hline IDN & -8.0 & 7.1 & 28.4 & 29.4 & 6.1 & 18.7 & 30.9 & -14.8 & 89.5 & 1.0 & 1.964 \\
\hline HKG & -6.1 & 5.8 & 19.7 & 26.2 & 0.3 & 19.6 & 29.6 & -10.0 & 0.28 & 6.4 & 46,036 \\
\hline CMB & -3.1 & 0.3 & 22.0 & 9.4 & 2.9 & 22.4 & 24.1 & -1.7 & 31.5 & -12.5 & 1.655 \\
\hline CHN & 2.3 & 5.0 & 43.6 & 45.6 & 2.3 & 25.5 & 36.9 & -11.4 & 66.8 & 2.0 & 10,483 \\
\hline BTN & -6.8 & 3.7 & 34.4 & 14.4 & 4.1 & 29.4 & 32.2 & -2.8 & 120,7 & $-12,1$ & 3,358 \\
\hline BGD & 2.4 & 5.3 & 27.7 & 26.2 & 5,6 & 9.5 & 15.0 & -5.5 & 38.8 & $-1,4$ & 1,998 \\
\hline ర్రి & 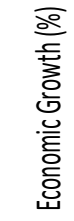 & 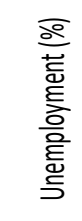 & 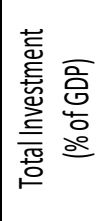 & 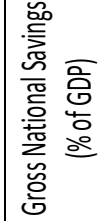 & 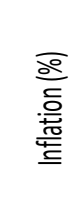 & 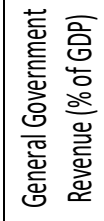 & 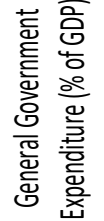 & 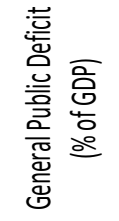 & 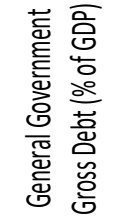 & 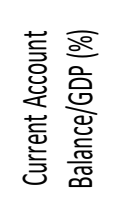 & 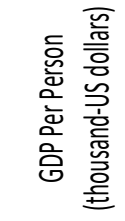 \\
\hline
\end{tabular}


Güngör Göksu, G. (2021). "Budgetary Responses to the Pandemic and Comparison of the Stringency Level of Interventions in Turkey and Asian Countries", International Journal of Public Finance, 6(2), 263-290.

\begin{tabular}{|c|c|c|c|c|c|c|c|c|c|c|c|}
\hline VNM & 6.5 & 2.7 & 28.1 & 30.4 & 3.8 & 15.9 & 20.6 & -5.3 & 47.9 & 2.3 & 3,609 \\
\hline TWN & 4.7 & 3.8 & 23.1 & 40.8 & 0.9 & 15.0 & 17.8 & -2.8 & 32.5 & 14.4 & 32,122 \\
\hline TUR & 5.8 & 12.9 & 29.9 & 26.6 & 8.0 & 28.2 & 33.9 & -5.7 & 37.1 & -3.4 & 8,661 \\
\hline THA & 2.5 & 1.5 & 24.4 & 24.8 & 1.5 & 21.0 & 25.9 & -4.9 & 55.9 & 0.45 & 7,701 \\
\hline SGP & 5.1 & -2.8 & 24.3 & 38.9 & 0.1 & 19.2 & 19.4 & -0.2 & 129.5 & 14.5 & 64,103 \\
\hline PNG & 3.4 & - & - & - & 3.6 & 14.3 & 19.7 & -5.4 & 49.5 & 21.7 & 2,737 \\
\hline PHL & 6.8 & 7.4 & 17.8 & 17.4 & 3.3 & 18.2 & 25.6 & -7.4 & 51.8 & -0.4 & 3,646 \\
\hline PAK & 1.4 & 5.0 & 15.5 & 13.9 & 8.6 & 15.7 & 22.8 & -7.1 & 87.6 & -1.5 & 3,346 \\
\hline NPL & 2.8 & - & 37.9 & 31.7 & 4.2 & 21.2 & 30.2 & -8.8 & 49.6 & -6.2 & 1,235 \\
\hline MYS & 6.5 & 3.8 & 22.5 & 26.3 & 2.0 & 19.4 & 23.8 & -4.4 & 66.9 & 3.8 & 11.603 \\
\hline MNG & 5.0 & 6.7 & 32.3 & 20.6 & 5.4 & 29.2 & 34.8 & -5.6 & 77.8 & $\mid-11.7$ & 4,171 \\
\hline MMR & -8.8 & - & 32.2 & 29.7 & 5.0 & 14.9 & 21.8 & -6.9 & 49.0 & -2.5 & 1,422 \\
\hline LAO & 4.6 & - & - & - & 4.9 & 13.3 & 18.9 & -5.6 & 68.8 & -7.4 & 2,773 \\
\hline LKA & 4.0 & 5.6 & 27.2 & 24.9 & 4.4 & 10.6 & 21.1 & -10.4 & 105.4 & -2.3 & 3,829 \\
\hline KOR & 3.5 & 4.6 & 32.6 & 36.8 & 1.3 & 22.7 & 25.6 & -2.9 & 53.1 & 4.2 & 34,865 \\
\hline JPN & 3.2 & 2.7 & 25.4 & 29.0 & 2.7 & 33.6 & 43.0 & -9.4 & 256.4 & 3.6 & 42,927 \\
\hline IND & 4.3 & 6.5 & 32.4 & 31.1 & 2.0 & 12.4 & 18.5 & -6.1 & 41.3 & -1.3 & 4,256 \\
\hline IDN & 12,5 & - & 30.0 & 28.8 & 4.8 & 19.2 & 29.2 & -10.0 & 86.5 & -1.1 & 2,190 \\
\hline HKG & 4.8 & 5.2 & 19.8 & 25.3 & 5.2 & 20.2 & 24.9 & -4.7 & 0.9 & 5.4 & 49.036 \\
\hline СМВ & 4.1 & - & 22.0 & 9.4 & 2.9 & 22.4 & 24.1 & -1.7 & 31.5 & $\mid-17.9$ & 1,720 \\
\hline $\mathbf{C H N}$ & 8.4 & 3.6 & 43.7 & 45.2 & 1.1 & 25.9 & 35.5 & -9.6 & 69.6 & 1.6 & 11,819 \\
\hline BTN & -1.9 & - & 40.8 & 27.1 & 4.9 & 24.9 & 30.5 & -5.6 & 123.3 & -8.7 & 3,296 \\
\hline BGD & 5.0 & - & 31.2 & 31.5 & 5.7 & 9.2 & 15.2 & -6.8 & 40.1 & 0.3 & 2,122 \\
\hline 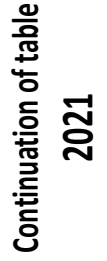 & 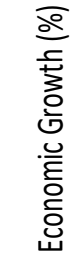 & 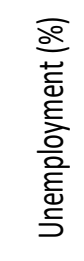 & 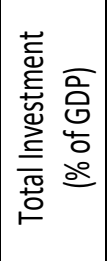 & 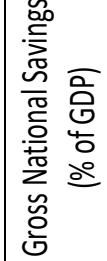 & 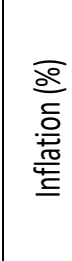 & 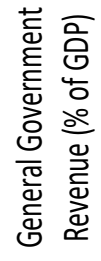 & 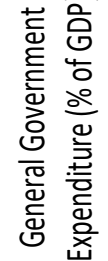 & 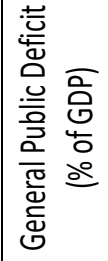 & 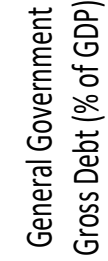 & 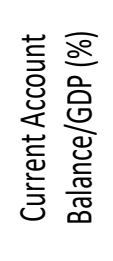 & 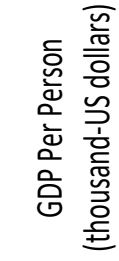 \\
\hline
\end{tabular}

References: IMF Database (2021), World Bank Database (2020), OECD Database (2020b). 


\section{A Comparison of Stringency Levels in Responses to the Pandemic by Selected Asia Countries}

To compare the rigour and consistency of pandemic responses in the selected Asian countries, the study used data from OxCGRT. OxCGRT has addressed the need for up-to-date, easily usable, and comparable information on COVID-19 policy actions since January 2020. Since the pandemic outbreak, OxCGRT has been calculating index scores by collecting 20 indicators on government responses using public information (Hale et al., 2021). In some studies, the relationship between the stringency of government interventions and case numbers were compared using only the stringency index; these include studies on the following geographical areas: Southeast Asia. (Lee et al., 2020); Italy, Spain, France, the United Kingdom, Germany, and Turkey (Kaçak \& Yıldız, 2020); South Asia (Yadav \& Igbal, 2021); and East Asia (Chen et al. 2021). However, the present study analyses the scores of four indices across selected countries and provides a comparative overview of the situations in Turkey and the East, South and Southeast Asian regions. As noted above, when comparing countries' responses, it is preferable to analyse the average data from March 11, 2020 to February 28, 2021. Graph 2 presents the scores of three indices-the containment health system responses (CHSR), economic support responses (ESR), and government responses $(G R)$ in the selected Asian countries.

Graph 2. Average Index Scores of Governments' Responses to the Pandemic

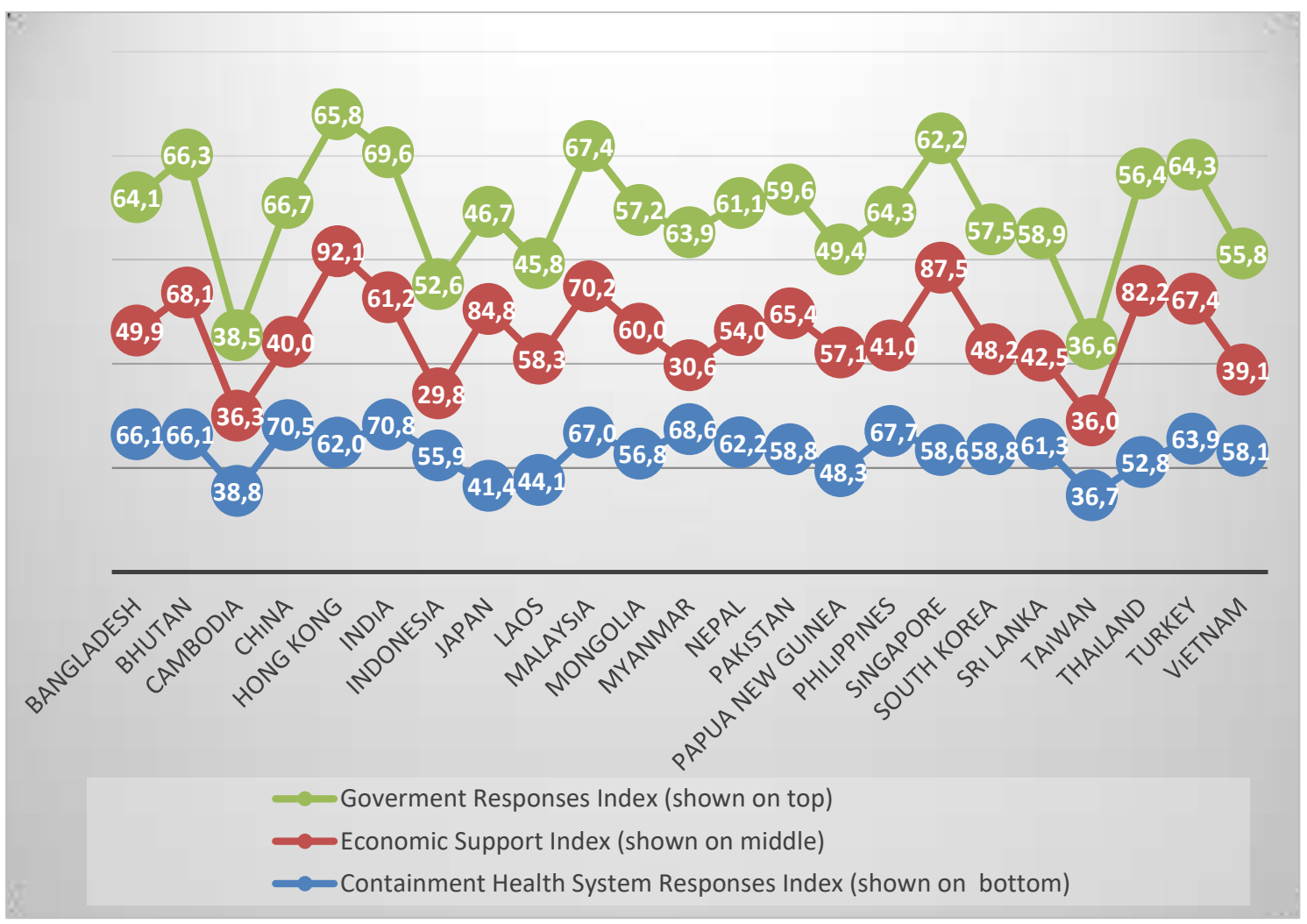

Note: Calculated the index scores for all countries by using the daily data from OxCGRT. Source: Hale et al., 2021. 
If the CHSR index scores of the countries in the date range are compared, the highest score belongs to India, with an index value of 70.8 out of 100 , while the lowest index value belongs to Taiwan, with 36.7. This result is closely linked to the number of cases because India is one of the countries with the highest number of cases worldwide. While Taiwan has had nearly 30,000 cases in total, there have been more than 12 million cases in India since the outbreak began. After India, the countries that display the highest indices are China, Myanmar, the Philippines, and Malaysia; the countries with the lowest indices after Taiwan are Cambodia, Laos, Japan, and Papua New Guinea.

The South Asia region was the least affected during the initial phase of the COVID-19 pandemic, and the recovery rate in this region was significantly better than in other parts of Asia (Yadav \& Igbal, 2021). If Asian countries are classified in regions, the average health index is 64.2 in South Asia, 54.4 in East Asia, and 56.0 in Southeast Asia. Furthermore, the index values for health system responses from all countries in the figure generally differ between 50 and 70 . The mean value of the indices of the countries analysed in the study is 58.1. The Turkish index score is 63.9 in relation to the total number of cases. Turkey, which has an above average value, is identified as one of the countries that have implemented intensive health system measures in the fight against the pandemic.

Relative to the CHSR score, a slight decrease in ESR occurred, and the average ESR index has stood at 56.6. Hong Kong, Singapore, Japan, Thailand, and Malaysia performed best, and it is understood that these countries have implemented rigorous and consistent economic measures to address the issues arising from the pandemic. By contrast, Indonesia, Myanmar, Taiwan, Cambodia, and Vietnam have the weakest economic support scores. The ESR index, which is mainly related to countries' levels of economic advancement, has averaged 60.2 in East Asia, 56.9 in South Asia, and 53.2 in Southeast Asia. The countries of East Asia have experienced remarkable economic growth in the last few decades. While China and Japan have, respectively, be the world's second and third largest economies, Hong Kong and Korea have become key centres for global financial services and technology (Kim et al. 2020). On the contrary, economies in Southeast Asia have been directly affected by COVID-19, and the extent of the economic downturn has varied from country to country, reflecting the political choice between containing the pandemic and supporting economic activities (Lee et al., 2020). In the case of Turkey, the ESR index of 67.4 is higher than that of most other countries, as well as the average value of the index. With respect to the GR index, the countries analysed achieved similar results, and there are no significant differences between them, except for Cambodia and Taiwan. Examining index values by region, the average rating is 63.3 in South Asia, 55.6 in South Asia, and 55.0 in East Asia. In addition, the average GR score for all countries studied is 57.9 , with the highest value at 69.6 points belonging to India. While Taiwan and Cambodia recorded the weakest results at 36.6 and 38.5, respectively, the GR index of Turkey, at 64.3, is above average. Graph 3 presents information on the proportion of COVID-19 cases in the total population and the stringency index scores of the countries analysed. 
Graph 3. The Proportion of Total Cases in the Population (\%) and Stringency Index Scores

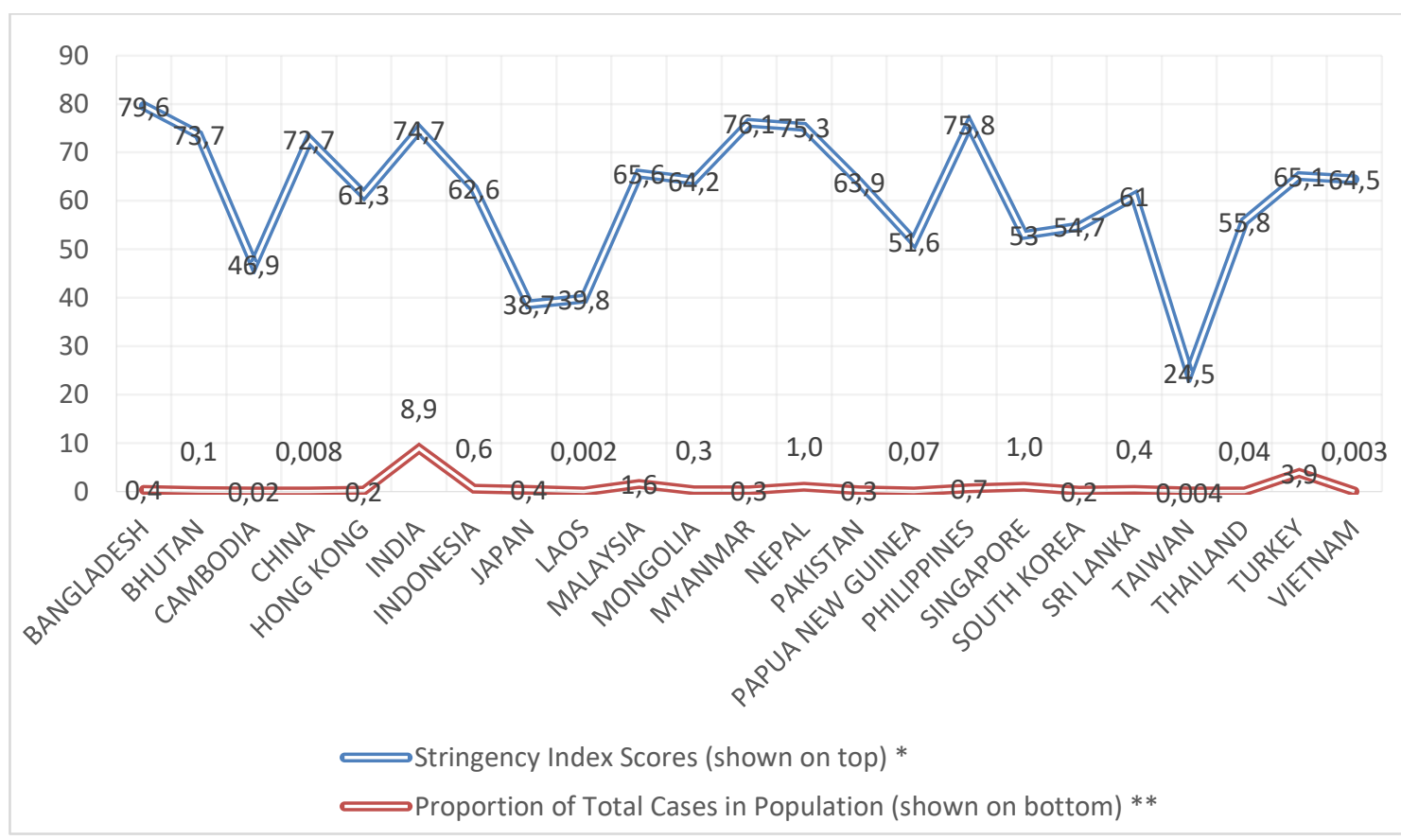

* Calculated index scores for all countries using daily OxCGRT data.

** Calculated using UN Global Demographic Outlook 2020 and WHO Coronavirus (COVID-19) data as of April 02, 2021.

Source: Hale et al., 2021; UN, 2020; WHO, 2021.

The last index by OxCGRT examined in this study is the stringency index, which has been prepared across a standardized series of ordinal, numeric, and textual indicators and transforms these indicators into a composite index (Hale et al., 2020). Indicators of the stringency index include measures such as lockdowns, school closings, workplace closings, public transportation closings, stay at home requirements, international travel bans, public event cancellations, gathering restrictions, and domestic travel limitations (Kaçak \& Yıldız, 2020). According to Figure 3, indices by country generally fluctuate between 60 and 70 points, and the average index for all countries combined is 61 . While the countries with the highest scores are Bangladesh, Myanmar, the Philippines, Nepal, and India, the countries with the lowest scores are Taiwan, Laos, Japan, and Cambodia. When countries are analysed in terms of regions, the stringency index averages for South Asia, East Asia, and Southeast Asia are 71.4, 52.7 , and 59.2, respectively.

India, Turkey, and Malaysia reported the highest proportion of COVID-19 cases within the total population. In some countries, such as Cambodia, Laos, and Taiwan, whose scores are below 50, the proportion of cases in the population is below 0.01 . Although China, Papua New Guinea, Thailand, and Vietnam have indices above 50.0, the proportion of total cases within the population of these countries have been less 
than 0.001. Taking these variables into account, it cannot be said that when the stringency index score increases, the proportion of cases decreases for all countries. For example, India and Turkey, which have indices of 74.7 and 65.1 respectively, have followed rigorous and consistent procedures; nevertheless, the case ratios remain very high in these countries.

The stringency level of government responses to COVID-19 is primarily driven by policy approaches, followed by experiences, collaboration culture with stakeholders, and citizens' adaptation levels. Particularly in East Asian countries, relatively low COVID-19 rates are strongly linked to robust responses, such as restructured and strong interventions, early and stringent mobility control, clear communication, compulsory self-protection practices, resource allocation, and supportive economic measures, as well as extensive screening, testing, tracing and isolation ( $\mathrm{Ma}$ et al. 2021). Moreover, it should not be forgotten that voluntary behaviours by members of civil society, along with collective actions by members of civil society and the bureaucracy, have contributed to flattening the COVID-19 curve (Wong, 2021). As of March 2021, the economic impact of the pandemic has been tragic, and less successful developing countries have implemented less significant economic and fiscal stimulus due to limited fiscal space (UNDP, 2021). To mitigate the impact of restraint and control measures and to re-launch the process of economic recovery, nearly all Asian governments have implemented economic recovery programs, and fiscal policies have led to both direct and indirect support of households and businesses (Lee et al., 2020). On the other hand, the uncertainty about when the pandemic will end continues. For this reason, governments should continue to provide fiscal measures such as credit guarantees, emergency liquidity support, and budgetary transfer payments up to emerging evidence indicators of a strong recovery (Bauer et al., 2021: 62). Especially, three areas are crucial importance to facilitate and support restructuring in the region (Bauer et al., 2021: 62).

i. "Reinforcing private debt resolution frameworks to "flatten the insolvency curve" and facilitate large scale corporate restructuring.

ii. Ensuring adequate financing to support corporate restructuring in the post pandemic recovery.

iii. Facilitating access to risk capital for existing firms and start-ups to speed up the reallocation of resources into growth sectors."

Table 6 displays the indicators used to calculate the economic support index and provides a comprehensive comparison of countries' economic responses to the economic problems of households affected by the pandemic. 
Table 6. Specific Economic Responses in the Selected Asian Countries

\begin{tabular}{|c|c|c|c|c|c|c|c|c|c|c|c|c|}
\hline $\begin{array}{l}\text { Specific economic } \\
\text { responses }\end{array}$ & 욤 & $\underset{n}{z}$ & 론 & $\sum_{U}^{\dot{\varphi}}$ & 产 & ż & $\underline{\underline{Z}}$ & za & 号 & $\underset{\Xi}{\Xi}$ & 운 & $\sum_{\Sigma}^{\mathscr{c}}$ \\
\hline E1. Income support & 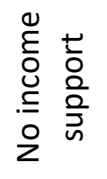 & 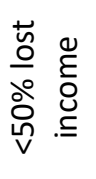 & 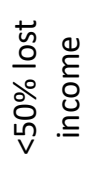 & 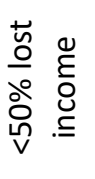 & 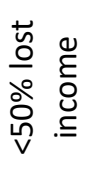 & 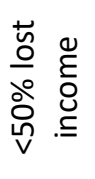 & 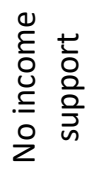 & 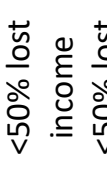 & 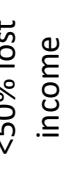 & 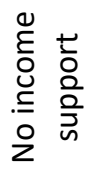 & 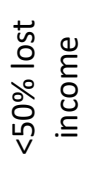 & 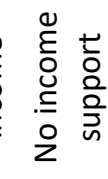 \\
\hline $\begin{array}{l}\text { E2. Debt/contract } \\
\text { relief for } \\
\text { households }\end{array}$ & 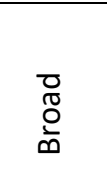 & 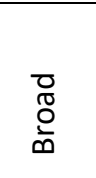 & 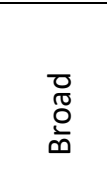 & $\begin{array}{l}0 \\
\stackrel{0}{0} \\
z\end{array}$ & 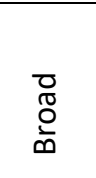 & $\frac{3}{0}$ & $\begin{array}{l}\text { D } \\
\text { D } \\
\stackrel{0}{0}\end{array}$ & $\begin{array}{l}\text { ㅁ } \\
\stackrel{0}{0} \\
\stackrel{0}{0}\end{array}$ & $\frac{3}{0}$ & $\begin{array}{l}\text { D } \\
\text { D } \\
\text { ஸे }\end{array}$ & $\begin{array}{l}\text { ర్ } \\
\text { o } \\
\text { ம }\end{array}$ & $\begin{array}{l}\text { ర0 } \\
\frac{0}{0} \\
\frac{0}{n}\end{array}$ \\
\hline $\begin{array}{l}\text { Specific economic } \\
\text { responses }\end{array}$ & $\sum_{\Sigma}^{0}$ & $\sum_{\Sigma}^{n}$ & $\overrightarrow{\underline{n}}$ & $\stackrel{ }{\stackrel{c}{a}}$ & 몸 & 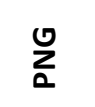 & 怘 & $\underset{\mathbb{1}}{\mathbb{1}}$ & $\stackrel{\Re}{\mathfrak{r}}$ & $\sum_{k}$ & & $\sum_{j}$ \\
\hline E1. Income support & 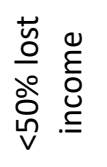 & 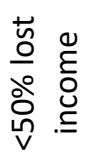 & 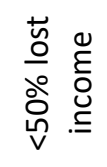 & 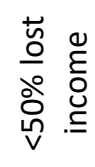 & 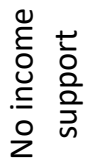 & 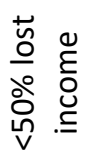 & 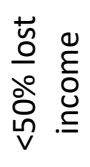 & 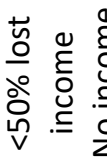 & 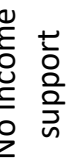 & 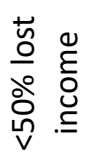 & & 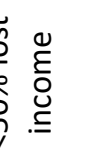 \\
\hline $\begin{array}{l}\text { E2. Debt/contract } \\
\text { relief for } \\
\text { households }\end{array}$ & $\begin{array}{l}\text { D } \\
\text { D } \\
\frac{0}{0}\end{array}$ & $\begin{array}{l}\text { D } \\
\text { O } \\
\frac{0}{\infty}\end{array}$ & $\begin{array}{l}3 \\
\frac{3}{2} \\
\frac{2}{\pi} \\
2\end{array}$ & $\begin{array}{l}\text { D } \\
\text { D } \\
\frac{0}{0}\end{array}$ & $\stackrel{0}{\frac{0}{0}}$ & 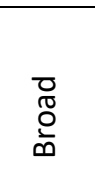 & 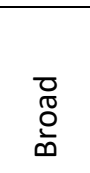 & $\begin{array}{l}\text { ㅁ } \\
\stackrel{0}{0} \\
\stackrel{0}{\infty}\end{array}$ & $\begin{array}{l}\stackrel{0}{c} \\
\frac{1}{z}\end{array}$ & $\begin{array}{l}3 \\
\frac{2}{2} \\
\frac{10}{2}\end{array}$ & & $\begin{array}{l}3 \\
\frac{2}{2} \\
\frac{1}{2} \\
2\end{array}$ \\
\hline
\end{tabular}

Note: Data in the table were collected on March 28, 2021, so the information is independent of the ESR scores in Graph 2; as mentioned, the ESR notes in the graph refer to the period between March 11, 2020 and February 28, 2021.

Source: Hale et al., 2021.

Fiscal support measures mitigate the pandemic cost on economic. According to Table 6, income support for families affected by the pandemic is favoured in most countries, and most governments support vulnerable citizens who have lost half or more of their income. However, in a few countries, such as Bangladesh, India, Sri Lanka, Myanmar, the Philippines, and Turkey, income support was not affected as of March 28, 2021. As regards debt and contract relief for households, relevant measures have been implemented broadly or narrowly, except in Cambodia, the Philippines, and Turkey. While most countries considered in the study have broadly applied debt and contract relief, only Indonesia, Korea, Nepal, and Taiwan have preferred narrow implementation. 


\section{Conclusion and Evaluation}

This paper has analysed the impacts of COVID-19 on the macroeconomic and fiscal structure in the short and long term, and the actions taken by the Turkish government to mitigate the consequences of the pandemic. In the study, also the adverse effects of the pandemic have been compared in the selected East and Southeast Asia countries over the leading macro and fiscal indicators. In addition, it has considered the consistency and rigour of responses in both Turkey and countries in East, South and Southeast Asia from a comparative perspective. The study has found that the Turkish economy continued to grow despite the recession stemming from the outbreak around the world. Indeed, Turkey had the third fastest growing economy after China and Taiwan in 2020. However, other macroeconomic indicators have been negatively affected by the outbreak, and it is projected that the adverse effects of the pandemic will continue during the multiannual period between 2021 and 2023 due to a lack of knowledge regarding the end date of the disease.

As in other countries, unexpected effects on Turkey's fiscal indicators have started to emerge due to the pandemic. For example, budgetary expenditures increased by $10 \%$ compared to the initial budget allowances. In addition, the EUdefined government debt, which stood at 32\% in 2019, reached more than $40 \%$. However, unlike most countries, Turkey has preferred a policy of raising interest rates to contain both inflation and exchange rates. Thus, the effects of high interest rates are reflected in the overall budget deficit. It is expected that the increase in the budget deficit will reach the 2019 level by the end of 2023. On a positive note, total budgetary revenues were $8 \%$ higher than initial budget revenue estimates due to the increase in the rates of private consumption taxes on motor vehicles, as well as the rise in interest, shares, and penalties. This increase in revenues prevented further increases in government expenditures. Among the expenditure items, only the current expenditures item, including transfer and subsidy payments to businesses and households, increased in the budget and accounted for the maximum share in the 2020 expenditure budget. The Turkish government has undertaken serious interventions to solve problems stemming from the outbreak, and all responses related to health, economic, and social services have added further costs to the central government budget.

In terms of East and Southeast Asia countries, it has been observed that the pandemic caused the increase within the general public deficit, the government gross debt level, unemployment level, and current accounts deficit in 2020. On the contrary, the crisis led to a sharp decrease in economic growth, total investment, gross national savings, and GDP per person. From an optimistic point of view, in 2021, it is projected that a remarkable recovery in economic structure will arise and, for example; it is estimated that the economic growth will reach a positive outlook in all analysed countries, except for Bhutan (-1.9\%) and Myanmar (-8.8\%) in the region. However, while the percentage of the public deficit in the GDP in most countries will continue to decrease, only Papua New Guinea (from $-6.2 \%$ to -5.4 ) and Singapore (from $9.0 \%$ to $0.2 \%)$ will display a positive outlook. 
COVID-19 has the feature of the first major outbreak in Turkey. Consequently, the Turkish government did not have as much experience responding to pandemics as some Asian countries, where SARS and MERS cases were detected. In the study, the rigour and consistency of Turkey's responses to the pandemic were compared with those of experienced Asian countries to understand whether the Turkish government has taken the pandemic seriously and addressed its tragic effects sufficiently. In terms of the scores of its CHSR, ESR, and GR indices, Turkey responded with strong interventions, scoring higher than the average of all analysed countries, and achieved strong results. Furthermore, except for Taiwan, East Asian countries, such as China, Hong outperformed countries in other parts of Asia. The main reasons that East Asian countries applied more rigorous and comprehensive policy instruments to the pandemic were differences in economic development and cultural structure among countries. In addition, past experiences with pandemics played an important role in the fight against COVID-19.

When comparing stringency index scores by OxCGRT, the Turkish index score has been higher than those of most other countries included in the study. However, the proportion of cases within the total population of Turkey was around $4 \%$, the second highest proportion after India. When different Asian regions in the study were compared, South Asian countries had the highest average stringency index, at 71.4. This is believed to result from the high proportion of cases in the total population of countries in this region. Although the economic responses used in the ESR index vary, the overall tendency in most countries in the study has been to provide income support and to apply for debt and contract relief for households. However, as of March 28,2021 , neither income support nor debt contract relief for households was valid in Turkey or the Philippines. It is, therefore, possible that the ESR index values will decrease in these countries.

COVID-19 has, directly and indirectly, affected health, economy, and social life in Turkey. Compared to the Asian countries examined in this study, Turkey has intervened decisively in these problems, although it has not previously encountered epidemics. However, all interventions have resulted in additional costs for the central government budget. Moreover, increases in borrowing and expenditure are projected to continue until the end of 2023 because an atmosphere of uncertainty remains worldwide, and Turkey is experiencing a third wave of COVID-19 as of April 2021.

\section{Funding}

This work was not supported by any institution or funding source.

\section{Disclosure statement}

No potential conflict of interest was reported by the author. 


\section{References}

Asia Development Bank. (2007). "Trade and Structural Change in East and Southeast Asia: Implications for Growth and Industrialization", https://www.adb.org/ sites/default/files/publication/27709/part01-trade.pdf., (15.10.2021).

An, B.Y., \& Tang, S.T. (2020). "Lessons From COVID-19 Responses in East Asia: Institutional Infrastructure and Enduring Policy Instruments", American Review of Public Administration, 50(6-7), 790-800.

Ando, M., Furukawa, C., Nakata, D., \& Sumiya, K. (2020). “Fiscal Responses to the COVID-19 Crisis in Japan: The First Six Month", National Tax Journal, 73(3), 901-926.

Andrew, J, Baker, M., Guthrie, J., \& Martin-Sardesai, A. (2020). “Australia's COVID-19 Public Budgeting Response: the Straitjacket of Neoliberalism", Journal of Public Budgeting, Accounting \& Financial Management, 32(5), 759-770.

Anessi-Pessina, E., Barbera, C., Langella, C., Manes-Rossi, F., Sancino, A., Sicilia M., \& Steccolini, I. (2020). "Reconsidering Public Budgeting after the COVID-19 Outbreak: Key Lessons and Future Challenges", Journal of Public Budgeting, Accounting \& Financial Management, 32(5), 957-965.

Ahrens, T. \& Ferry, I. (2020). "Financial Resilience of English Local Government in the Aftermath of COVID-19", Journal of Public Budgeting, Accounting \& Financial Management, 32(5), 812-823.

Argento, D., Kaarbøe, K., \& Vakkuri, J. (2020). “Constructing Certainty through Public Budgeting: Budgetary Responses to the COVID-19 Pandemic in Finland, Norway and Sweden", Journal of Public Budgeting, Accounting \& Financial Management, 32(5), 875-887.

Ashfaq, M. \& Bashir, M. (2020). "Pakistan: Making a 'COVID budget' in a Struggling Economy", Journal of Public Budgeting, Accounting \& Financial Management, 33(1), 69-77.

Balajee, A., Cafral, S. T., \& Udupa, G. (2020). "Fiscal Situation of India in the Time of COVID-19", Indian School of Business, 1-27.

Bauer, A., Craig R.S., Garrido J., Kang K., Kashiwase K., Kim S.J., Liu Y., \& Rafiq S. (2021). "Flattening the Insolvency Curve-Promoting Corporate Restructuring in Asia and the Pacific to Support the Post-Pandemic Recovery", in C. Y. Rhee \& K. Svirydzenka (Eds.), Policy Advice to Asia in the COVID-19 Era (61-66). Paper No. 21/04, International Money Fund Publishing, Washington, USA.

Beh, L-S., \& Lin, W.L. (2021). "Impact of COVID-19 on ASEAN Tourism Industry", Journal of Asian Public Policy, DOI: 10.1080/17516234.2020.1871180.

Bloomberg HD (2020, 13 March). Albayrak: İstikrar Kalkanı Adımlarımızın Maddi Tutarı 240 Milyar TL'ye Ulaştı, [Albayrak: The financial amount of our Stability Shield 
steps reached 240 billion TL], https://www.bloomberght.com/albayrak-istikrarkalkani-adimlarimizin-maddi-tutari-240-milyar-tl-ye-ulasti-2255323, (6.7.2021).

Bostan, S., Erdem, R., Öztürk, Y. E., Kılıç, T., \& Yılmaz, A. (2020). “The Effect of COVID19 Pandemic on the Turkish Society", Electronic Journal of General Medicine, 17(6), 2-8.

Chan, S. P. (2020, March 23). "Global Economy will Suffer for Years to Come, Says OECD", BBC News, https://www.bbc.com/news/business-52000219, (8.7.2021).

Chen, S. X., Lam, B. C. P., Liu, J. H., Choi, H-S., Kashima, E., \& Bernardo, A.B.I. (2021). "Effects of Containment and Closure Policies on Controlling the COVID-19 Pandemic in East Asia", Asian Journal of Social Psychology, 24, 42-47.

Christensen, T., \& Lægreid, P. (2020). “Balancing Governance Capacity and Legitimacy: How the Norwegian Government Handled the COVID-19 Crisis as a High Performer", Public Administration Review, 80(5), 774-779.

Clemens, J., \& Veuger, S. (2020). Implications of the COVID-19 pandemic for state government tax revenues, (Working Paper no. 27426), National Bureau of Economic Research.

Driessen, G. A. (2020). The Coronavirus relief fund (CARES Act, Title V): Background and state and local allocations, (Report no. 7), Congressional Research Service.

Djalante, R., Nurhidayah, L., Minh, H. V., Ngoc Phuong, T. N., Mahendradhata. Y., Trias, A., Lassa, J., \& Miller, M. A. (2020). "COVID-19 and ASEAN Responses: Comparative Policy Analysis", Progress in Disaster Science, 8, 1-12.

Dutta, A., \& Fischer, H. W. (2020). "The Local Governance of COVID-19: Disease Prevention and Social Security in Rural India", World Development, 138, 1-11.

Dünya (2021, 23 January). "2020 Yılı Bütçe Gerçekleşmeleri, Sapmalar”, [Budget Realizations in 2020, Deviations], https://www.dunya.com/kose-yazisi/2020yili-butce-gerceklesmeleri-sapmalar/608058, (14.8.2021).

DW Turkey (2021, 1 March). "Ekonomi Büyüdü ama Vatandaş Fakirleşti", [The Economy Grew, but the Citizen Became Poor], https://www.dw.com/tr/ ekonomi-b\%C3\%BCy\%C3\%BCd\%C3\%BC-ama-vatanda\%C5\%9F-fakirle\%C5\%9Fti /a-56738681, (14.8.2021).

Economics and Social Comission for Asia and the Pasific (ESCAP) (2020). "The Impact and Policy Responses for COVID-19 in Asia and the Pacific", https://www.unescap.org/sites/default/files/COVID\%20_Report_ESCAP.pdf, (19.10.2021).

Food and Agriculture Organisation of the United Nations (2021). MERS-CoV Situation Update, $\quad$ http://www.fao.org/ag/againfo/programmes/en/empres/mers/ situation_update.html, (11.6.2021).

Felix, A. (2020). "COVID-19 Challenges State and Local Government Finances", kcFED Economic Bulletin, Federal Reserve Bank of Kansas City, the USA. 
Ferry, L., \& Eckersley, P. (2011). "Budgeting and Governing for Deficit Reduction in the UK Public Sector: Act One 'The Comprehensive Spending Review', Journal of Finance and Management in Public Service, 10(1), 14-23.

Furman, J., Geithner, T., Hubbard, G., \& Kearney, M. S. (2020). Promoting Economic Recovery after COVID-19, The Aspen Institute, Economic Strategy Group.

Grossi, G., Ho, A. T. \& Joyce, P. G. (2020). “Budgetary Responses to a Global Pandemic: International Experiences and Lessons for a Sustainable Future", Journal of Public Budgeting, Accounting \& Financial Management, 32(5), 737-744.

Gössling, S., Scott, D., \& Hall, C. M. (2021). "Pandemics, Tourism and Global Change: A Rapid Assessment of COVID-19", Journal of Sustainable Tourism, 29(1), 1-20.

Güngör Göksu, G. (2020). Küresel Salgına Yönelik Alınan Mali Önlemlerin Bütçe ve Borçlanma Üzerine Etkileri, [The effects of the fiscal measures taken against the global epidemic on the budget and borrowing], in H. Kılıçaslan (Ed.). COVID-19: Küresel Pandeminin Ekonomik ve Mali Etkileri [COVID-19: Economic and Financial Impacts of the Global Pandemic], (71-98). Gazi Publisher.

Hale, T., Angrist, N., Goldszmidt, R., Kira, B., Petherick, A., Phillips, T., Webster, S., Blake, E. C., Hallas, L., Majumdar, S., \& Tatlow, H. (2021). “A Global Panel Database of Pandemic Policies, (Oxford COVID-19 Government Response Tracker), Nature Human Behaviour, 5, 529-538.

Hsiao, F. S. T. \& Hsiao, M.-C. W. (2006). "FDI, Exports, and GDP in East and Southeast Asia-Panel Data Versus Time-Series Causality Analyses", Journal of Asian Economics, 1082-1106.

Heald, D., \& R. Hodges (2020). "The Accounting, Budgeting and Fiscal Impact of COVID19 on the United Kingdom", Journal of Public Budgeting, Accounting \& Financial Management, 32(5), 785-795.

International Monetary Fund (2021). World Economic Outlook Database, https://www.imf.org/en/Publications/WEO/weo-database/2021/April/selectcountry-group, (10.5.2021).

International Monetary Fund. (2020a). World Economic Outlook: A Long and Difficult Ascent. https://www.imf.org/en/Publications/WEO/Issues/2020/09/30/worldeconomic-outlook-october-2020, (1.4.2021).

International Money Fund (2020b). Challenges in Forecasting Tax Revenue. https://www.imf.org/ /media/Files/Publications/covid19-special-notes/enspecial-series-on-covid-19-challenges-in-forecasting-tax-revenue.ashx?la=en, (1.4.2021).

Jose, J., Mishra, P., \& Pathak, R. (2020). "Fiscal and Monetary Response to the COVID19 Pandemic in India", Journal of Public Budgeting, Accounting \& Financial Management, 33(1), 56-68. 
Kaçak, H. \& Yıldız, M. S. (2020). "Stringency of Government Responses to COVID-19 and Initial Results: A Comparison Between Five European Countries and Turkey", Türk Hijyen ve Deneysel Biyoloji Dergisi, 77(2): 233-242.

Kim, B. H. (2020). "Budgetary Responses to COVID-19: The Case of South Korea", Journal of Public Budgeting, Accounting \& Financial Management, 32(5), 939-947.

Kim, W. J., Trung, N. X., Hung, L. V., \& Trung, N. N. (2020). "Relationship Between Cultural Values and Well-Being: Analysis From Some East Asian Countries", Journal for Cultural Research, 24(4), 334-350.

Lee, C., Negara, S. D. \& Sambodo, M. T. (2020). Covid-19's Economic Reckoning in Southeast Asia. (Publication no. 107). Yusof Ishak Institute.

Liao, W.-J., Kuo, N.-L., \& Chuang, S.-H. (2020). "Taiwan's Budgetary Responses to COVID-19: The Use of Special Budgets", Journal of Public Budgeting, Accounting \& Financial Management, 33(1), 24-32.

Ma, M., Wang, S., \& Wu, F. (2020). COVID-19 Prevalence and Well-Being: Lessons From East Asia. World Happiness Report. https://worldhappiness.report/ed/2021/ covid-19-prevalence-and-well-being-lessons-from-east-asia/, (31.3.2021).

McDonald, S., S. Robinson, S. \& K. Thierfelder (2008). Asian Growth and Trade Poles: India, China, and East and Southeast Asia. World Development, 36(2): 210-234. doi:10.1016/j.worlddev.2007.06.013.

McNichol, E., Leachman, M., \& Marshall, J. (2020). States Need Significantly More Fiscal Relief to Slow the Emerging Deep Recession, The Center on Budget and Policy Priorities. https://www.cbpp.org/research/state-budget-and-tax/statesneed-significantly-more-fiscal-relief-to-slow-the-emerging, (18.3.2021).

Mok, K. H., Ku, Y.-W., \& Yuda, T. K. (2021). "Managing the COVID-19 Pandemic Crisis and Changing Welfare Regimes", Journal of Asian Public Policy, 14(1), 1-12.

Mori, H. \& Elder, M. (2010). Economic and Environmental Impact of Free Trade in East and South East Asia, Springer, Dordrecht, Heidelberg, London, New York.

Nemec, H-J., \& Spacek, D. (2020). "The Covid-19 Pandemic and Local Government Finance: Czechia and Slovakia", Journal of Public Budgeting, Accounting \& Financial Management, 32(5), 837-846.

NTV (2020, 8 September). "Fitch, Türkiye İçin Büyüme Tahminini Yukarı Yönlü Revize Etti, [Fitch revised upwards its growth forecast for Turkey]. https://www.ntv.com.tr/ekonomi/fitch-turkiye-icin-buyume-tahminini-yukariyonlu-revize etti,Y47K7CF6CkCgQZqr3IsWQQ

Ohno, K. (2002). East Asian Experience in Economic Development and Cooperation, National Graduate Institute for Policy Studies, https://www.grips.ac.jp/ forum/pdf02/PN3.pdf, (15.10.2021).

Olivia, S., Gibson, J., \& Nasrudin, R. (2020). "Indonesia in the Time of Covid-19", Bulletin of Indonesian Economic Studies, 56(2), 143-174. 
Organisation for Economic Co-Operation and Development (2021a). Economic Outlook for Southeast Asia, China and India 2021, Reallocating Resources for Digitalisation, https://doi.org/10.1787/711629f8-en, (16.10.2021).

Organisation for Economic Co-Operation and Development (2021b). Quarterly National Accounts: G20 - Quarterly Growth Rates of GDP, https://stats.oecd.org/, (1.4.2021).

Organisation for Economic Co-Operation and Development (2020a). Economic Outlook. 1, 107, OECD, Paris, France.

Organisation for Economic Co-Operation and Development (2020b). OECD National Account Data, https://www.oecd.org/sdd/na/, (10.10.2021).

Oh, S.-Y. (2020). "From a "Super Spreader of MERS" to a, "Super Stopper," of COVID19: Explaining the Evolution of South Korea's Effective Crisis Management System", Journal of Asian Public Policy, 1-16.

Özcan, Y. (2020). "Impact of COVID-19 Pandemic on Tax Revenues", Journal of Istanbul Commerce University Social Sciences, 19 (37), 342-354.

Presidency of Strategy and Budget (2020a). Presidential Annual Program 2021. https://www.sbb.gov.tr/wpcontent/uploads/2020/11/2021_Yili_Cumhurbaska nligi_Yillik_Programi.pdf, (24.3.2021).

Presidency of Strategy and Budget (2020b). Medium Term Programme 2019-2021, 2020-2022, and 2021-2023. https://www.sbb.gov.tr/orta-vadeli-programlar/, (24.3.2021).

Raudla, R. \& Douglas, J. W. E. (2020). "This Time was Different: The Budgetary Responses to the Pandemic-Induced Crisis in Estonia", Journal of Public Budgeting, Accounting \& Financial Management, 32(5), 847-854.

Şanver, C. (2020). COVID-19 Salgınının Cari Transfer Harcamalarına Etkisi [The Effects of COVID-19 Outbreak on Current Transfer Expenditures]. in H. Kılıçaslan (Ed.). COVID-19: Küresel Pandeminin Ekonomik ve Mali Etkileri [COVID-19: Economic and Financial Impacts of the Global Pandemic] (119-142). Gazi Publisher.

The Central Bank of the Republic of Turkey (2021). Interest ratios statistics. https://tcmb.gov.tr/wps/wcm/connect/TR/TCMB+TR/Main+Menu/Temel+Faali yetler/Para+Politikasi/Merkez+Bankasi+Faiz+Oranlari/faiz-oranlari, (25.3.2021).

The Ministry of Treasury and Public Finance (2021). Public Finance Statistics, https://www.hmb.gov.tr/kamu-finansmani-istatistikleri, (24.3.2021).

The Turkish Revenue Administration (2021). Tax Statistics. https://www.gib.gov.tr/ yardim-ve-kaynaklar/istatistikler, (20.3.2021).

Turkish Statistical Institute (2021). The GDP Growth Statistics. https://data.tuik.gov.tr/ Bulten/Index?p=D\%C3\%B6nemsel-Gayrisafi-Yurt-\%C4\%B0\%C3\%A7i-Has\%C4\% B1la-IV.-\%C3\%87eyrek:-Ekim---Aral\%C4\%B1k,-2020-37180\&dil=1, (25.3.2021). 
United Nations Development Programme (2021). Responding to the Covid-19 Pandemic Leaving no Country Behind, (Publication no. SPR210111-2), UNDP, DOI: http://dx.doi.org/10.22617/SPR210111-2.

United Nations (2020). World Population Prospects. https://population.un.org/ wpp/Download/Standard/Population/, (2.4.2021).

United Nations Industrial Development Organization (2010). Structural Change and Sectoral Growth in Selected East Asian Countries, Working Paper 18/2009, Vienna, Austria.

Upadhaya, B., Wijethilake, C., Adhikari, P., Jayasinghe, K., \& Arun, T. (2020). “COVID-19 Policy Responses: Reflections on Governmental Financial Resilience in South Asia", Journal of Public Budgeting, Accounting \& Financial Management, 32(5), 825-836.

We are self-sufficient Turkey, (2020, March 24). https://bizbizeyeteriz.gov.tr/, (2.4.2021).

Williams, A. (2020). "Stabilizing State and Local Budgets Through the Pandemic and Beyond Through Beyond", Economics Policy Note Archive, 20(2), Levy Economics Institute of Bard College.

Withers, M., Henderson, S., \& Shivakoti, R. (2021). "International Migration, Remittances and COVID-19: Economic Implications and Policy Options for South Asia", Journal of Asian Public Policy, DOI: 10.1080/17516234.2021.1880047.

Wong, W. (2021). "When the State Fails, Bureaucrats and Civil Society Step Up: Analysing Policy Capacity with Political Nexus Triads in the Policy Responses of Hong Kong to COVID-19", Journal of Asian Public Policy, DOI: 10.1080/17516234.2021.1894314.

World Bank (2020). World Bank Open Data. https://data.worldbank.org/, (10.10.2021).

World Health Organisation (2021). Coronavirus (COVID-19) Dashboard, WHO, https://covid19.who.int/, (2.4.2021).

Wu, S., \& Li, M. (2020). "Analysing the Chinese Budgetary Responses to COVID-19: Balancing Prevention and Control with Socio-Economic Recovery", Journal of Public Budgeting, Accounting \& Financial Management, 32(5), 929-937.

Vakulenko, V., Khodachek, I., \& Bourmistrov, A. (2020). "Ideological and Financial Spaces of Budgetary Responses to COVID-19 Lockdown Strategies: Comparative Analysis of Russia and Ukraine", Journal of Public Budgeting, Accounting \& Financial Management, 32(5), 865-874.

Yadav, A., \& Iqbal, B. A. (2021). "Socio-Economic Scenario of South Asia: An Overview of Impacts of COVID-19", South Asian Survey, 28(1), 20-37. 